\title{
Financial Efficiency and Economic Growth in Thailand
}

\author{
Chollada Luangpituksa \\ Kasetsart University, Bangkok, Thailand
}

\begin{abstract}
This paper investigates the relationship between financial efficiency and economic growth in Thailand with annual time series during 1991-2015. Financial efficiency measures: (i) bank efficiency in intermediating savings to investment, as measured by the net interest margin (the accounting value of bank's net interest revenue as a share of its average interest-bearing assets) (IMARGIN) and lending-deposit spread (ISPREAD); and (ii) operational efficiency measures, such as overhead costs to total assets; NONILIA while the percentage change of real GDP per capita (real gross domestic product [RGDP]) represents economic growth. The Augmented Dickey-Fuller Test (ADF) of the stationary test shows that all data are stationary at the first difference except ISPREAD is stationary at the second difference. Since all variables are not integrated at the same order, there are no short run and long run relationship between financial efficiency variables and economic growth. The pairwise Granger causality result with 1 lagged length selected by Akaike Information Criterion (AIC), shows that no causality between financial efficiency variables and economic growth and vice versa; and supports the "neutral hypothesis". However, there is a one-way causality linkage between two financial efficiency indicators, lending and deposit interest rate spread, and the ratio of overhead costs to total assets. In other words, the banks' profit from interest spread is used to improve bank efficiency, such as hiring more staff, increase number of branches, and automatic teller machines (ATMs) to improve bank services. Therefore, financial institutions should provide financial services to response customers' needs as the commercialization and modernization of the economy.
\end{abstract}

Keywords: financial efficiency, economic growth, Granger causality, lending-deposits spread, net interest margin, overhead cost

\section{Introduction}

Financial sector is a set of institutions, instruments, markets to facilitate surplus, and deficit units in the economy. Financial development is the process to reduce costs of acquiring information, enforcing contracts, and making transactions in order to provide better job for five key functions of the financial sector which are: (i) producing information about possible investments and allocating capital; (ii) monitoring investments and exerting corporate governance after providing finance; (iii) facilitating the trading, diversification and management of risk; (iv) mobilizing and pooling savings; and (v) easing the exchange of goods and services. It consists of depth (size and liquidity of markets), access (ability of individuals and companies to access financial services), stability (capability of efficiently allocating resources, and assessing and managing financial risks), and efficiency (ability of institutions to provide financial services at low cost with sustainable revenues, and the level of activity of capital markets).

The nexus of financial development and economic growth is shown by a lot of evidence that financial development promotes economic growth through capital accumulation and technological progress by 
increasing savings rate, mobilizing and pooling savings, producing information about investment, facilitating and encouraging the inflows of capital, as well as optimizing the allocation of capital (World Bank, 2018).

The relationship between financial development and economic growth on the theoretical level has always been controversial. Khan and Senhadji (2000), Khan, Qayyum, and Sheikh (2005), Shan and Qi (2006), Caporale, Rault, R. Sova, and A. Sova, (2009), and Gemma, Park, and Ramayandi (2010) showed the supply leading hypothesis or Schumpeterian view of finance in growth which notes that financial development causes economic growth particularly in developed countries. On the other hand, Robinson (1952) and Lucas (1988) believed that financial intermediaries develop in response to demand from the real sector or it is called "the demands following hypothesis". This is supported by some empirical studies, such as Kenza and Benbouziane (2015), and Ogbuagu and Ewubare (2017).

Since 1970s, most of empirical literature approximates four measures of financial depth: (i) liquid liabilities of the financial system divided by GDP; (ii) ratio of bank credit divided by bank credit plus central bank domestic assets; (iii) the share of credit allocated to private enterprises to total domestic credit (excluding credit to banks); and (iv) credit to private enterprises divided by GDP. With the passage of time, financial sectors have evolved across the globe and modern financial systems have become multifaceted. The diversification of financial system implies that more indicators should be considered for financial development, such as financial access, financial stability, financial efficiency, and financial openness.

Financial institutions efficiency relies on three aspects of bank efficiency: (i) efficiency in intermediating savings to investment, as measured by the net interest margin (the bank's net interest revenue as a share of its average interest-bearing assets) and thus represents the net interest return on income producing assets, and lending-deposit spread; (ii) operational efficiency measures, such as non-interest income to total income and overhead costs to total assets; and (iii) profitability measures, such as return on assets and return on equity (Svirydzenka, 2016).

The empirical debate has been on the direction of causality and the measurement of financial development. Four basic hypotheses have been proposed to address the question relating to the direction of causality:

1. Does the development of the financial system cause economic growth (supply-leading hypothesis)?

2. Does growth in economic activity cause a development of the financial system (demand-following hypothesis)?

3. Is there bi-directional causality between financial development and economic growth (feedback hypothesis)?

4. Is there no causal relationship between financial development and economic growth (neutral hypothesis)?

For over five decades, the direction of causality between financial development and economic growth has remained a contentious and unresolved issue and studies on the subject matter have produced mixed results across countries and periods.

Thailand has been moved from a low-income country to an upper-income country within the last four decades with sustained strong growth and impressive poverty reduction, particularly in the 1980s (World Bank, 2017). This economic growth has been driven by national development plans from the National Economic and Social Development Board (NESDB) as well as investment promotion policy by the Board of Investment (BOI). Hence, capital can come from both domestic saving and foreign investors. Thai commercial banks have played significant roles in mobilizing, pooling saving, and providing loans for domestic consumption and investment 
for a century. Since an establishment of the stock Exchange of Thailand (SET) in 1975, source of fund from equities has gradually increased. After Thai economy has been recovered from the financial crisis to normal in 2001, the Bond Exchange Market (BEX) has become vital. Capital fund from the bank lending has dropped from 90 percent to 50 percent, while the equities have jumped from 5 percent to 40 percent and the debt instruments have risen from 0.38 percent to 10 percent during 1992 and 2015. Moreover, the dramatic growth of equities over the bank credit has been noticed since 2007.

Thus this study wants to observe whether financial efficiency particularly the banking system exerts economic growth in Thailand. The remaining of this paper is organized as follows: Section 2 conducts an extensive survey of the literature on empirical studies; data and methodology used in the empirical analysis are presented in Section 3; Section 4 examines the causality relationship of financial efficiency in the Thai banking system on economic growth by Granger causality test; and some conclusion and recommendation are offered in Section 5.

\section{Literature Review}

In the early 20th century, most of studies have examined the relationship between financial development and economic growth by using financial depth as a measure for financial development. Levine (1997) reviewed that the first study was conducted by Goldsmith (1969) which used data of 35 countries from 1860 to 1963 and found that rapid economic growth have been accompanied by rate of financial development measured by the value of financial intermediary assets divided by gross national product (GNP). Mckinnon (1973) inspected the same issue in Argentina, Brazil, Chile, Germany, Indonesia, Korea, and Taiwan in the post-World War II period. He found that better functioning financial systems stimulate faster growth. Shaw (1973) introduced supporting evidence that financial intermediaries promote investment and raise output growth through borrowing and lending as concluded by Alrabadi (2016).

The succeeding papers use different models, techniques, and control variables on both the aggregate and individual country levels and find a positive impact of financial development on economic growth. Levine (1997) had cited his research with King in 1993 that by using 80 countries data over the period 1960-1989 for regression model analysis, it has been found that there is a strong correlation between real per capita GDP and financial depth. Subsequent study by Darrat (1999) in three middle-eastern countries; Saudi Arabia, Turkey, and the United Arab Emirates during 1964-1993, also supports the view that financial deepening is a necessary causal factor of economic growth, although the strength of the evidence varies across countries and across the proxies used to measure financial deepening. The study of Levine, Loayza, and Beck (2000) pointed to the same conclusion that financial development has a positive impact on economic growth.

The similar result also has been supported in the case of individual country. Bhatti (2015) indicated positive relationship between financial depth and economic growth in Pakistan. Karimo and Ogbonna (2017) confirmed that the growth-financial deepening nexus in Nigeria follows the supply-leading hypothesis. However, Adusei (2013) explored evidence that financial development undermines economic growth in Ghana.

The Granger causality test has been introduced to examine the direction of causal relationship between financial development and economic growth recently. Odhiambo (2008) discovered unidirectional causal flow from economic growth to financial depth during 1969-2005 in Kenya. The results also reveal that economic growth Granger causes savings, while savings drive the development of the financial sector in Kenya. On the contrary, the study of causal relationship between financial development and economic growth in Sri Lanka by 
Perara and Paudel (2009) suggested that broad money causes economic growth with two-way causality but the major finding of this study does not strongly support the view that financial development boosts economic growth. Interestingly, the empirical study of Ogunyiola (2013) in Cape Verde indicated the existence of a long run relationship between economic growth and financial development variables. However, no short run relationship exists between economic growth and financial development variables. The study also discover a unidirectional relationship running from financial development to economic growth when money supply (M2) is used as well as a bidirectional causality running from financial development to economic growth and vice versa, when domestic credit provided by commercial bank is used. The study reveals a unidirectional causality from economic growth to domestic credit to private sector. Sami, Blotevogel, Fischer, and Shi (2017) cited in their research that the global financial crisis has been a turning point. They cannot confirm clearly a positive relationship between financial development and economic growth followed the study of Rousseau and Watchel (2011) which discovered that the finance-growth relationship disappears during the period between 1990 and 2004.

As regards the mechanism through which financial development affects growth for individual country, Ang (2007) found that financial development, private capital stocks, and the labour force exert a positive impact on economic development whereas the accumulation of public capital appears to curtail output expansion in the long run in Malaysia. Chakraborty (2014) also discovered that financial deepening has significant contribution to economic development but financial deepening creates volatility in the capital market and capital market deepening has great contribution in the economic growth of the country.

The measurement of financial development has been expanded to efficiency of the banking institutions by Ferreira (2012) using bank cost efficiency and also the concentration of the bank markets, measured by the percentage share of the total assets held by the three largest banking institutions and the Herfindahl-Hirschman Index for all $27 \mathrm{EU}$ countries for the time period between 1996 and 2008. The main findings point to the generally positive influence of bank cost efficiency on economic growth. With regard to the bank market concentration, a generally negative influence not only on GDP, but also on the gross fixed capital formation, as well as for the export and import of goods and services. Saqib (2013) used broad money, M2 to GDP, and the ratio of private to GDP as indicators of financial sector development and interest spread as indicator of financial sector efficiency to test the relationship for a sample of 50 developing countries for a data averaged over the period 2005-2009. The result supports that financial sector development is crucial for economic growth and the efficiency of the financial sector is potentially important for the long-term growth performance of the developing countries.

\section{Data and Methodology}

\section{Data and Sources}

This study uses annual data for the time span of 1991 to 2015. The data on economic growth (RGDP) are the annual percentage change of real per capita gross domestic product (GDP) collected from the World Development Indicators of the World Bank. The financial efficiency indicators are calculated from the Bank of Thailand statistical data and they are the followings:

1. Interest spread (ISPREAD) is the difference of commercial banks' lending and three-month deposit interest rate;

2. Net interest margin (IMARGIN) measures by the share of interest received to interest paid; 
3. The ratio of overhead cost to banks' total assets (NONILIA).

\section{Model Specification}

This study undertakes a comprehensive set of econometric test for the empirical analysis; unit root tests, optimal lag length for the Vector Autoregressive (VAR) model and Pairwise Granger causality test. For unit root test, the Augmented Dickey-Fuller (ADF) test is the most commonly used test, it nevertheless requires homoscedastic and uncorrelated errors in the underlying structure. The VAR model is estimated to examine the short run dynamic effect of financial deepening on economic growth.

$$
\mathrm{RGDP}_{\mathrm{t}}=\alpha+\emptyset_{1} \mathrm{RGDP}_{\mathrm{t}-\mathrm{p}}+\emptyset_{\mathrm{P}} \mathrm{RGDP}_{\mathrm{t}-\mathrm{p}}+\beta_{1} \mathrm{FD}_{\mathrm{t}-1}+\beta_{\mathrm{p}} \mathrm{FD}_{\mathrm{t}-\mathrm{p}}+e_{t}
$$

Where RGDP denotes economic growth, FD denotes financial efficiency. To select the appropriate lag structure of all variables, Akaike Information Criteria (AIC) and Schwarz Criteria (SC) are used. Thereafter, Granger causality tests are performed as follows:

$$
\begin{gathered}
\mathrm{RGDP}_{\mathrm{t}}=\alpha_{1}+\sum_{\mathrm{i}=1}^{\mathrm{n}} \mathrm{B}_{\mathrm{i}} \mathrm{FD}_{\mathrm{t}-\mathrm{i}}+\sum_{\mathrm{j}=1}^{\mathrm{n}} \lambda_{\mathrm{j}} \mathrm{RGDP}_{\mathrm{t}-\mathrm{j}}+\mathrm{e}_{1 \mathrm{t}} \\
\mathrm{FD}_{\mathrm{t}}=\alpha_{2}+\sum_{\mathrm{i}=1}^{\mathrm{n}} \theta_{\mathrm{i}} \mathrm{RGDP}_{\mathrm{t}-\mathrm{i}}+\sum_{\mathrm{j}=1}^{\mathrm{n}} \phi_{\mathrm{j}} \mathrm{FD}_{\mathrm{t}-\mathrm{j}}+\mathrm{e}_{2 \mathrm{t}}
\end{gathered}
$$

\section{Results and Discussion}

The three financial efficiency proxies (IMARGIN, ISPREAD, and NONILIA) and economic growth (RGDP) are time series data therefore they must be tested for stationary before running the causality test. For this purpose, the $\mathrm{ADF}$ test at the proper lag length one year is used. Table 1 illustrates the unit roots (non-stationary) tests for four variables; IMARGIN, ISPREAD, NONILIA, and RGDP respectively comprising the ADF test at the 5\% level of significance, The ADF tests examine the null hypothesis of a unit root (non-stationary) is tested against the alternative hypothesis no unit root (stationary). The unit root tests models are estimated at levels, first difference, and second difference for none, intercept or constant, and trend and constant in each case. All the test statistics at level are insignificant so the null hypotheses of a unit root are accepted for all the variables investigated. The next step is to difference the variables once in order to perform stationary on differenced variables. The results of ADF tests on the first differences confirm that IMARGIN, NONILIA, and RGDP are stationary except the variable ISPREAD is stationary at the second difference. Since these variables are not integrated at the same order, therefore there are no co-integration or no statistically short run and long run relationship between financial efficiency and economic growth.

Table 2 suggests the appropriate lag structure of all variables by applying the VAR test. The smallest value for Likelihood Ratio (LR), Akaike Information Criteria (AIC), and Schwarz Criteria (SC) is at lag 1. Therefore, the optimal lag length should be at lag 1 because AIC test is more suitable than the other criteria under study in the case of small sample (60 observations and below) (Liew, 2004; Ivanov \& Kilian, 2005).

Table 3 reports the results of the Granger causality tests between economic growth and financial efficiency. The result indicates that there is no causal relationship between financial efficiency for all indicators and economic growth and vice versa at the 5\% level of significance. Thus, the development of financial sector on efficiency does not affect economic growth as well as an economic growth does not lead financial efficiency in banking system. However, there is unidirectional causality between interest spread to the ratio of overhead cost to banks' total assets or interest spread affects overhead cost. In other words, commercial banks can get profit from the difference of lending and deposit interest rate and may use it for quality improvement in services, such as increasing the number of branches and ATM machines, hiring more staff, introducing new computer software application for Internet or mobile banking, and constructing new banking offices. 
In summary, the result that the financial efficiency and economic growth has no linkage in Thailand during this period, lend some support to the "neutral hypothesis" view as Sami et al. (2017).

Table 1

Augmented Dickey-Fuller Test Statistics (Constant, Linear Trend)

\begin{tabular}{llll}
\hline Variables & T-Statistic & Prob. & Result \\
\hline At levels & & & Non-stationary \\
\hline IMARGIN & -3.147722 & 0.1194 & Non-stationary \\
ISPREAD & -2.078415 & 0.5300 & Non-stationary \\
NONILIA & -2.129158 & 0.5037 & Non-stationary \\
RGDP & -2.837510 & 0.1992 & Stationary \\
\hline At the first-difference & & & Non-Stationary \\
IMARGIN & -4.208480 & 0.0161 & Stationary \\
ISPREAD & -2.912264 & 0.1777 & Stationary \\
NONILIA & -3.988973 & 0.0250 & \\
GDP & -4.386147 & 0.0112 & Stationary \\
\hline At the second-difference & & & \\
IMARGIN & - & - & 0.0220 \\
ISPREAD & -4.072729 & - & - \\
NONILIA & - & & \\
RGDP & - & & \\
\hline
\end{tabular}

Table 2

Optimal Lag Length

\begin{tabular}{|c|c|c|c|c|c|}
\hline Data trend: & None & None & Linear & Linear & Quadratic \\
\hline Rank or & No Intercept & Intercept & Intercept & Intercept & Intercept \\
\hline No. of CEs & No Trend & No Trend & No Trend & Trend & Trend \\
\hline \multicolumn{6}{|c|}{ Log likelihood by rank (rows) and model (columns) } \\
\hline 0 & -59.62034 & -59.62034 & -57.77343 & -57.77343 & -53.40217 \\
\hline 1 & -58.26299 & -52.56785 & -52.56785 & $-49.91382^{*}$ & $-49.91382^{*}$ \\
\hline \multicolumn{6}{|c|}{ Akaike information criteria by rank (rows) and model (columns) } \\
\hline 0 & 5.601849 & 5.601849 & 5.524857 & 5.524857 & 5.218379 \\
\hline 1 & 5.660272 & 5.233441 & 5.233441 & $5.083075^{*}$ & $5.083075^{*}$ \\
\hline \multicolumn{6}{|c|}{ Schwarz criteria by rank (rows) and model (columns) } \\
\hline 0 & 5.701035 & 5.701035 & 5.673636 & 5.673636 & 5.416751 \\
\hline 1 & 5.858643 & 5.481405 & 5.481405 & $5.380632^{*}$ & $5.380632^{*}$ \\
\hline
\end{tabular}

Note. ${ }^{*}$ indicates lag order selected by the criterion

Table 3

Granger Causality Test $($ Lag $=1)$

\begin{tabular}{|l|l|l|}
\hline Null hypothesis & $p$-value & Result \\
\hline RGDP does not Granger Cause IMARGIN & 0.9911 & Accept \\
\hline IMARGIN does not Granger Cause RGDP & 0.9380 & Accept \\
\hline RGDP does not Granger Cause ISPREAD & 0.1510 & Accept \\
\hline ISPREAD does not Granger Cause RGDP & 0.8737 & Accept \\
\hline RGDP does not Granger Cause NONILIA & 0.0662 & Accept \\
\hline NONILIA does not Granger Cause RGDP & 0.9880 & Accept \\
\hline ISPREAD does not Granger Cause IMARGIN & 0.1630 & Accept \\
\hline IMARGIN does not Granger Cause ISPREAD & 0.3486 & Accept \\
\hline NONILIA does not Granger Cause IMARGIN & 0.0540 & Accept \\
\hline IMARGIN does not Granger Cause NONILIA & 0.8286 & Accept \\
\hline NONILIA does not Granger Cause ISPREAD & 0.4939 & Accept \\
\hline
\end{tabular}


\begin{tabular}{|l|l|l|}
\hline ISPREAD does not Granger Cause NONILIA & $0.0094^{*}$ & Reject \\
\hline
\end{tabular} Note. ${ }^{*}$ Reject null hypothesis at the statistical level 0.05 .

\section{Conclusion and Policy Recommendation}

The relationship between economic growth and financial efficiency in Thailand is investigated by using annual data over the period 1991-2015. Economic growth is measured by the annual percentage change of real per capita gross domestic product (GDP) while three proxies are employed for the financial efficiency. These proxies are the interest spread between commercial banks' lending rate and deposit rate, net interest margin, and the ratio of overhead cost to banks' total assets. The stationary test of time series data of used variables show that they do not integrate at the same order thus there is no co-integration or all proxies of financial efficiency do not relate to economic growth in Thailand and vice versa in the long run. From Granger causality tests, the result confirms that there is no statistically significant causality between financial efficiency and economic growth or economic growth and financial efficiency to support "neutral hypothesis". However, the difference of lending rate and deposit rate is one-way causality linkage to the ratio of non-interest expense to banks' total assets. Thus, commercial banks may spend their profits from interest spread to improve service quality for customers, such as opening new branches, increasing ATM machines, hiring more staff, and introducing computer software application for Internet banking and mobile banking.

\section{References}

Adusei, M. (2013). Financial development and economic growth: Evidence from Ghana. The International Journal of Business and Finance Research, 7(5), 61-76.

Alrabadi, D. W. H. (2016). Financial deepening and economic growth: The case of Jordan. Journal of Accounting and Finance, 16(6), 158-166.

Ang, J. B. (2007). Financial deepening and economic development in Malaysia. Retrieved from https://works.bepress.com/james_ang/3/Nanyang

Bhatti, M. S. M. (2015). Financial depth and economic growth in Pakistan: Analysis of governance approaches. Retrieved from https://www.researchgate.net/...Financial_depth_and_economic_growth_in_Pakistan

Caporale, G. M., Rault, C., Sova, R., \& Sova, A. (2009). Financial development and economic growth: Evidence from ten new EU members. Working Papers No. 09-37. Retrieved from https://bura.brunel.ac.uk/bitstream/2438/10915/1/Fulltext.pdf

Chakraborty, A. (2014). Financial deepening, economic development and capital market evidence from India. Retrieved from https:/www. pjitm.com/Doc/july-dec2014/62014.pdf

Darrat, A. F. (1999). Are financial deepening and economic growth causally related? Another look at the evidence. International Economic Journal, 13(3), 19-35.

Ferreira, C. (2012). Bank efficiency, market concentration and economic growth in the European Union. Working Papers Department of Economics 2012/38. Retrieved from https://ideas.repec.org/p/ise/isegwp/wp382012.html

Gemma E., Park, D., \& Ramayandi, A. (2010). Financial development and economic growth in developing Asia. ADB Economics Working Paper No. 233. Retrieved from https://www.adb.org/sites/default/files/publication/28277/economics-wp233.pdf

Goyal, R., Marsh, C., Raman, N., Wang, S., \& Swarnali, A. (2011). Financial Deepening and international monetary stability. IMF Discussion Note SDN11/16. Retrieved from https://www.imf.org/external/pubs/ft/sdn/2011/sdn1116.pdf

International Monetary Fund (IMF). (2012). Enhancing financial sector surveillance in low income countries: Financial deepening and macro-stability. Retrieved from https://www.imf.org/external/np/pp//eng/2012/041612.pdf

Ivanov, V. \& Kilian, L. (2007). A practitioner's guide to lag order selection for VAR Impulse Response Analysis. Studies in Nonlinear Dynamics \& Econometrics. 9. 1219-1219.

Karimo, T. M., \& Ogbonna, O. E. (2017). Financial deepening and economic growth nexus in Nigeria: Supply-leading or demand-following? Economies 2017, 5(4), 1-18.

Kenza, M., \& Benbouziane, M. (2015). Financial development and economic growth in Algeria: An econometric analysis of the transmission channels. EPRA International Journal of Economic and Business Review, 3(2), 5-15. 
Khan, A., Qayyum, A., \& Sheikh, S. (2005)). Financial development and economic growth: The case of Pakistan. The Pakistan Development Review, 44(4), 819-837.

Khan, M. S., \& Senhadji, A. S. (2000). Financial development and economic growth: An overview. IMF Paper Working, (WP/00/209). Retrieved from https://www.imf.org/ /media/Websites/IMF/imported-full-text-pdf/external/pubs/ft/wp/2000/_wp00209.ashx

Levine, R. (1997). Financial development and economic growth: Views and Agenda. Journal of Economic Literature, 35, 688-726.

Levine, R., Loayza, N., \& Beck, T. (2000). Financial intermediation and growth: Causality and causes. Journal of Monetary Economics, 46, 31-77.

Liew, V. K. S. (2004). Which lag length selection criteria should we employ? Economics Bulletin, 3(33), 1-9.

Lucas, R. E., Jr. (1988). On the mechanics of economic development. Journal of Monetary Economics, 22, 3-42.

McKinnon, R. I. (1973). Money and capital in economic development. Washington, DC: Brookings Institution.

Odhiambo, N. M. (2008). Financial depth, savings and economic growth in Kenya: A dynamic causal linkage. Economic Modelling, 25, 704-713.

Ogbuagu, A. R., \& Ewubare, D. B. (2017). Financial deepening implications for macro-economic volatility and economic growth in Nigeria: A Multivariate approach. International Journal of Economics, Finance and Management Sciences, 5(1), 66-80.

Ogunyiola, A. (2013). Financial development and economic growth: The case of Cape Verde. MPRA Paper No.49783. Retrieved from https://mpra.ub.uni-muenchen.de/49783/3/MPRA_paper_49783.pdf

Perara, N., \& Paudel, R. C. (2009). Financial development and economic growth in Sri Lanka. Applied Econometrics and International Development, 9(1), 157-164.

Robinson, J. (1952). The generalization of the general theory, in the rate of interest, and other essays. London: Macmillan, 67142.

Rousseau. P. \& Wachtel, P. (2011). What is happening to the impact of financial deepening on economic growth? Economic Inquiry, 49(1), 276-288.

Rudra P. P., Mak, B. A., Neville, R. N., \& Bennett, S. E. (2016). Financial depth, Internet penetration rates and economic growth: Country-panel evidence. Applied Economics, 48(4), 331-343.

Sahay, R., Cihak, M., N'Diaye, P., Barajas, A., Bi, R, Ayala, D., Yousefi, R. S. (2017). Rethinking financial deepening: Stability and growth in emerging markets. IMF Staff Discussion Note SDN/15/08. Retrieved from https://www.imf.org/external/pubs/ft/sdn/2015/sdn1508.pdf

Sami, B. N., Blotevogel, R., Fischer, M., \& Shi, H. (2017). Financial development and Source of growth: new evidence. IMF Working Paper, WP/17/143. Retrieved from https://www.imf.org/ /media/Files/Publications/WP/2017/wp17143.ashx

Sani, N. F. N. M, Ismail, I., \& Wan, M. W. M. (2015). Causal relationship between financial depth and economic growth: Evidence from Asia-Pacific countries. MPRA Paper No. 62188. Retrieved from https://mpra.ub.uni-muenchen.de/62188/1/MPRA_paper_62188.pdf

Saqib, N. (2013). Impact of development and efficiency of financial sector on economic growth: Empirical evidence from developing countries. Journal of Knowledge Management, Economics and Information Technology, 3, 1-15.

Shan, J., \& Qi, J. (2006). Does financial development "lead" economic growth? The case of China. Annals of Economics and Finance, 1, 197-216.

Shaw, E. S. (1973). Financial deepening in economic development. Oxford University Press, New York.

Svirydzenka, K. (2016). Introducing a new broad-based index of financial development. IMF Working Paper WP/16/5. Retrieved from https://www.imf.org/external/pubs/ft/wp/2016/wp1605.pdf

World Bank. (2017). Thailand overview. Retrieved from http://www.worldbak.org/e/country/thailand/overview

World Bank. (2018). Key terms explained. Global Financial Development Report 2017/2018: Bankers Without Borders. Retrieved from https://www.worldbank.org/en/publication/gfdr/background/key-terms-explained\#6 